\title{
Hipertensi Renovaskular
}

\author{
Afdhol Falah ${ }^{1}$, Harnavi Harun ${ }^{2}$
}

\begin{abstract}
Abstrak
Hipertensi renovaskular adalah peningkatan tekanan darah sistolik dan atau diastolik yang umumnya mendadak dan resisten akibat hipoperfusi ginjal yang biasanya disebabkan stenosis arteri renalis dan aktivasi sistem renin-angiotensin. Penyakit ini merupakan salah satu penyebab dari hipertensi sekunder yang dapat terjadi karena gangguan pada vaskular berupa stenosis arteri renalis, berkaitan dengan penyakit parenkim ginjal atau dapat juga merupakan kombinasi dari keduanya. Angka kejadiannya yaitu 1-4 \% dari seluruh penderita hipertensi. Hipertensi renovaskular lebih sering ditemukan pada usia remaja dibandingkan pada kelompok usia dewasa. Tujuan penatalaksanaan hipertensi renovaskular adalah memperbaiki oklusi arteri renalis sehingga hipoperfusi ginjal membaik dan tekanan darah menurun. Dalam kasus ini kami melaporkan seorang perempuan berusia 22 tahun datang dengan keluhan sakit kepala sejak 1 hari sebelum masuk rumah sakit. Hasil angiografi arteri renalis: stenosis $80-90 \%$ pada arteri renalis dextra. Selanjutnya pasien dilakukan Percutaneous Transluminal Renal Angioplasty. Setelah dilakukan pemasangan balon arteri renalis keluhan sakit kepala berkurang dan tekanan darah menjadi normal dan obat antihipertensi dihentikan.
\end{abstract}

Kata kunci: hipertensi renovaskular, stenosis arteri renalis, Percutaneous Transluminal Renal Angioplasty

\begin{abstract}
Renovascular hypertension is an increment in systolic and / or diastolic blood pressure which is generally abrupt and resistant due to renal hypoperfusion which is usually caused by renal artery stenosis and activation of the renin-angiotensin system (RAS). Renovacular hypertension can occur due to vascular disorders, related to renal parenchymal disease or the combination of both. Renovascular hypertension is $1-4 \%$ of all hypertensive patients. Renovascular hypertension is more common in adolescents than in the adult age group. The aim of renovascular hypertension management is to remedy renal artery occlusion in order to kidney hypoperfusion improves and blood pressure decreases. Herein we report a case of 22 years old female presenting with a headache 1 day prior to hospital admission. Renal artery angiography results: $80-90 \%$ stenosis in dextra renal arteries. Furthermore, the patient is performed Percutaneous Transluminal Angiography. After the installation of renal artery balloon, the headache complaint of this patient decreases and blood pressure becomes normal and the antihypertensive drugs is stopped
\end{abstract}

Keywords: renovascular hypertension, renal arterial stenosis, Percutaneous Transluminal Renal Angioplasty

Affiliasi penulis : 1. Program Studi Pendidikan Profesi Dokter Spesialis-1 IImu Penyakit Dalam FK Unand/RSUP Dr M Djamil Padang 2. Subbagian Ginjal Hipertensi Bagian IImu Penyakit Dalam FK Unand/RSUP Dr M Djamil Padang

Korespondensi : balthier37@ymail.com Telp: +6281274969565

\section{PENDAHULUAN}

Hipertensi renovaskular adalah peningkatan tekanan darah sistolik dan atau diastolik yang umumnya mendadak dan resisten akibat hipoperfusi ginjal yang biasanya disebabkan stenosis arteri renalis dan aktivasi sistem renin-angiotensin. ${ }^{1}$ Hipertensi renovakular dapat terjadi karena gangguan pada vaskular, berkaitan dengan penyakit parenkim ginjal atau dapat juga merupakan kombinasi dari keduanya. Hipertensi renovaskular merupakan 1-4 \% dari seluruh penderita hipertensi. Hipertensi renovaskular lebih sering ditemukan pada usia remaja dibandingkan pada kelompok usia dewasa. Tujuan penatalaksanaan hipertensi renovaskular adalah memperbaiki oklusi arteri renalis sehingga hipoperfusi ginjal membaik dan tekanan darah menurun. ${ }^{2}$

Manifestasi klinis hipertensi renovaskular sering asimptomatik dan ditemukan saat melakukan general check-up. Saat gejala muncul, biasanya tidak spesifik dan sering berkaitan dengan target organ yang dipengaruhi oleh hipertensi. Nyeri kepala, perubahan kesadaran, pandangan kabur dan muntah merupakan gejala yang umum. Perlu dipikirkan pada anak-anak, remaja, wanita muda, dan pria yang menderita aterosklerosis kemungkinan adanya penyakit oklusi arteri renalis bila mereka menderita hipertensi. Hal yang merupakan petunjuk hipertensi renovaskular adalah adanya hipertensi yang terjadi pada umur dibawah 30 tahun dengan tidak adanya riwayat keluarga yang menderita hipertensi, adanya kerusakan organ sebagai target hipertensi, hipertensi maligna, hipertensi yang tidak respon dengan penggunaan tiga obat antihipertensi, durasi pendek dengan progresifitas cepat dari hipertensi ringan ke berat, dan onset hipertensi yang jelas pada pasien yang sebelumnya normotensi. Pemeriksaan fisik untuk menegakkan diagnosa ditunjukkan dengan adanya bruit. Auskultasi pada punggung di sudut kostovertebralis kadang-kadang dapat menemukan bruit. Bruit abdominal yang terdapat pada epigastrium atau kuadran atas merupakan gambaran diagnostik yang penting. ${ }^{3}$

Pasien dengan $\geq 2$ kriteria dibawah ini dianjurkan untuk dilakukan pemeriksaan yang mengarah kepada hipertensi renovaskular. ${ }^{3}$

- Hipertensi yang terjadi secara mendadak atau memburuk dan pada usia $>55$ tahun atau $<30$ tahun.

- Adanya bruit abdominal.

- Hipertensi yang resisten dengan tiga jenis atau lebih obat antihipertensi. 
- Adanya peningkatan kadar kreatinin serum $\geq 30 \%$ setelah penggunaan angiotensin II receptor antagonist.

- Penyakit pembuluh darah aterosklerosis lainnya, khususnya pasien dengan kebiasaan merokok atau memiliki dislipidemia.

- Edema paru berulang akibat hipertensi yang tidak terkontrol.

Pemeriksaan berikut dapat direkomendasikan sebagai pemeriksaan penyaring tambahan pada rumah sakit rujukan untuk penyakit vascular renal: captopril-enhanced radioisotope renal scan, Sonografi Dopler, Magnetic resonance angiography, dan CTangiography (untuk pasien dengan fungsi ginjal normal). Captopril-enhanced radioisotope renal scan tidak direkomendasikan untuk pasien dengan CKD $\left(\right.$ GFR<60 mL/min $\left./ 1,73 \mathrm{~m}^{2}\right){ }^{3}$

Angiografi merupakan gold standard dalam penegakan diagnosis hipertensi renovaskular. Indikasi dilakukan angiografi ini mencakup pada pasien dengan: ${ }^{4}$

1. Aterosklerosis berat

2. Hipertensi berat atau hipertensi resisten

3.Gagal ginjal yang tidak dapat dijelaskan penyebabnya

4. Riwayat oedem paru

Angiografi dengan menggunakan kateter langsung, walaupun lebih invasif dibandingkan semua pemeriksaan lainnya, tapi memiliki kelebihan yang bermakna dalam menilai pasien hipertensi renovaskular. Dengan teknologi terkini, pemeriksaan dapat dilakukan dengan kateter yang sangat kecil dan kontras minimal $(<20 \mathrm{ml})$. Resiko terjadinya cedera pada arteri kecil, resolusi spatial yang bagus, dan jika penanganan stenosis diperlukan, kateter sudah berada pada tempatnya. Displasia fibromuskular dan stenosis pada percabangan yang sering luput pada pemeriksaan lainnya, dapat terlihat jelas pada pemeriksaan ini. Pada pasien dengan kecurigaan klinis yang tinggi terhadap stenosis arteri renalis, pemeriksaan ini sering menjadi satu-satunya pemeriksaan terbaik yang perlu dilakukan. CT angiografi merupakan pemeriksaan non invasiv yang cukup akurat. Pemeriksaan ini memiliki sensitivitas $94 \%$ dan spesifisitas $93 \%$ tetapi memiliki nefrotiksisitas dari bahan kontras. Magnetic Resonance Angiography adalah tes non invasif untuk menilai stenosis arteri renalis. ${ }^{4,5}$

Terapi hipertensi renovaskular dengan obatobatan seringkali gagal dalam mengatasi hipertensi, namun dari berbagai referensi terapi medikamentosa tetap dimasukkan ke dalam bentuk terapi hipertensi renovaskular. ${ }^{6}$

Meskipun kesembuhan dari hipertensi pada pasien-pasien dengan arterosklerotik adalah jarang $(<25 \%)$, namun perbaikan dalam pengendalian hipertensi didapati pada $34 \%-90 \%$ pasien yang diterapi dengan Percutaneous Transluminal Renal Angioplasty (PTRA) yang merupakan terapi pilihan untuk mengatasi stenosis arteri renalis akibat diplasia fibromuskular. Hasil PTRA secara bermakna lebih baik pada dispalsia fibromuskular, dengan penelitian yang telah diterbitkan, bahwa hipertensi dapat dikendalikan pada $76 \%$ - $100 \%$ pasien. PTRA efektif mengontrol tekanan darah dengan keberhasilan $80 \%$ pada bulan pertama postintervensi hingga $93 \%$ pada evaluasi 2 tahun setelah intervensi. ${ }^{7}$

\section{LAPORAN KASUS}

Seorang wanita usia 22 tahun dirawat di bangsal penyakit dalam RSUP Dr M. Djamil dengan keluhan utama sakit kepala sejak 1 hari sebelum masuk rumah sakit, sakit kepala sudah dirasakan sejak 3 minggu sebelumnya, hilang timbul, sakit dirasakan diseluruh kepala

Pemeriksaan fisik didapatkan keadaan umum baik, tekanan darah pada lengan kanan, lengan kiri, tungkai kanan, dan tungkai kiri didapatkan hasil secara berurutan yaitu 190/120 $\mathrm{mmHg}, 160 / 90$, sistolik $180 \mathrm{mmHg}$, sistolik $155 \mathrm{mmHg}$, nadi $92 \mathrm{kali} /$ menit regular, nafas $20 \mathrm{kali} / \mathrm{menit}$ dan temperatur $37^{\circ} \mathrm{C}$. Mata konjungtiva tidak anemis, sklera tidak ikterik. Jantung dan paru-paru dalam batas normal. Pemeriksaan abdomen ditemui bising pada regio hipokondrium kanan dan regio costovertebre angle kanan dan tidak ditemukan edema pada kedua tungkai.

Hasil laboratorium: Darah rutin dalam batas normal, urinalisa didapatkan dalam batas normal. Fungsi ginjal: ureum dan kreatinin dalam batas normal, profil lipid dalam batas normal. Rontgen thorak PA ditemukan jantung dan paru dalam batas normal. Hasil USG ginjal: sonografi kedua ginjal sesuai dengan gambaran ginjal normal. Hasil angiografi arteri renalis: stenosis $80-90 \%$ pada arteri renalis dextra. Hasil funduskopi didapatkan retinopati hipertensi KW I.

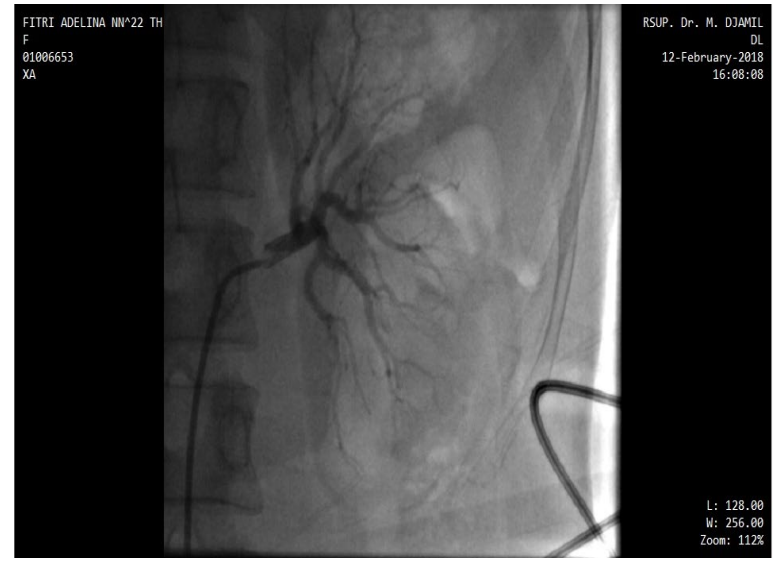

Gambar 1. Angiografi renal sinistra (normal)

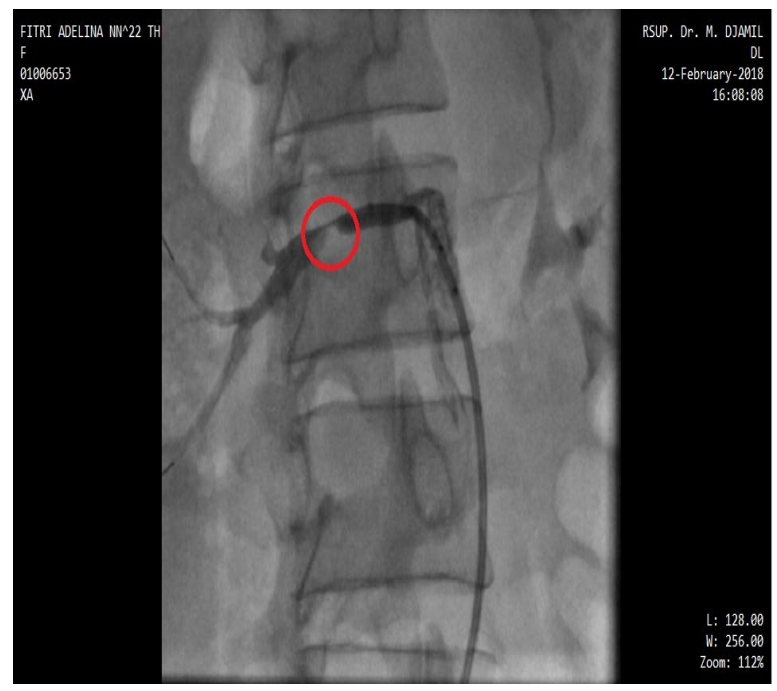

Gambar 2. Stenosis arteri renalis dextra 
Pasien didiagnosis dengan hipertensi sekunder ec stenosis arteri renalis dextra. Selanjutnya pasien dilakukan Percutaneus Transluminal Angiography.

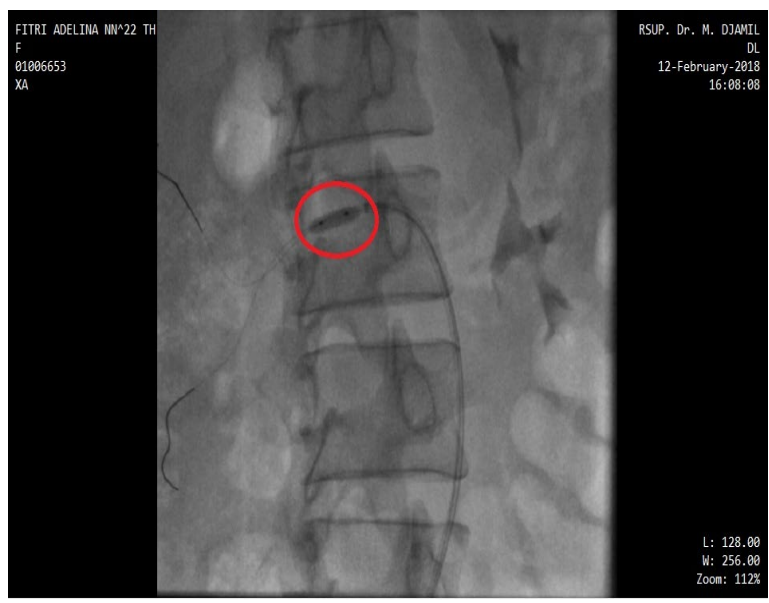

Gambar 3. Pemasangan balon arteri renalis dextra

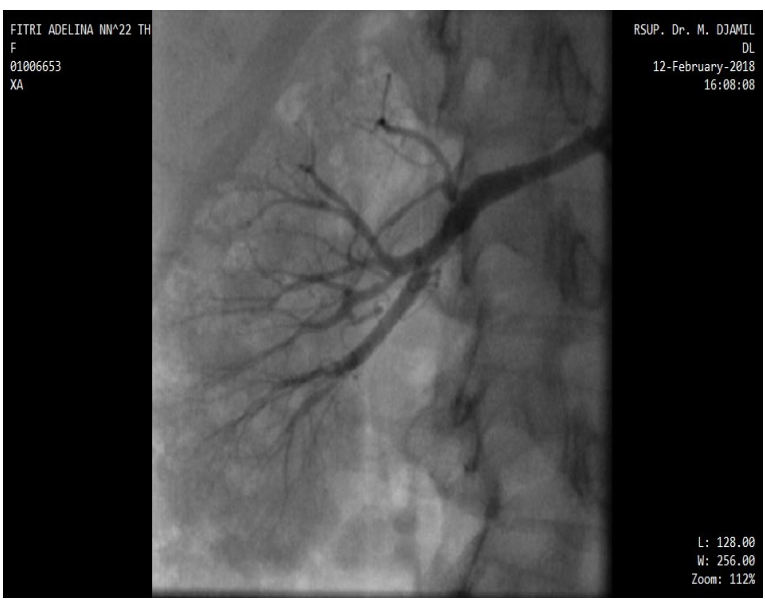

Gambar 4. Post PTRA arteri renalis dextra

Setelah dilakukan pemasangan balon arteri renalis, keluhan sakit kepala pada pasien ini berkurang dan tekanan darah menjadi $110 / 70 \mathrm{mmHg}$ dan obat antihipertensi dihentikan.

\section{DISKUSI}

Telah dirawat Seorang pasien perempuan, usia 22 tahun, di bangsal Penyakit Dalam RSUP Dr M. Djamil dengan diagnosis Hipertensi sekunder ec renovaskular.

Diagnosis ditegakkan berdasarkan anamnesis, pemeriksaan fisik, pemeriksaan laboratorium dan pemeriksaan penunjang. Pada anamnesa ditemukan adanya sakit kepala, riwayat keluarga yang tidak ada hipertensi sebelumnya, dan peningkatan tekanan darah yang terjadi pada usia muda. Pemeriksaan fisik ditemukan tekanan darah yang lebih dari $200 / 120 \mathrm{mmHg}$ dan adanya tanda retinopati hipertensi KW I. Pemeriksaan penunjang laboratorium tidak ditemukan adanya kelainan. Pemeriksaan penunjang radiologis yang lain tidak selalu dapat dilakukan karena memerlukan biaya mahal dan tidak selalu tersedia. Angiografi dilakukan merupakan baku emas pemeriksaan dan ditemukan adanya stenosis arteri renalis dextra sebesar $90 \%$.
Skrining dilakukan pada kelompok pasien yang mempunyai gambaran klinik yang mencurigakan kemungkinan hipertensi renovaskular yaitu: Hipertensi yang timbul pada usia kurang dari 30 tahun atau lebih dari 50 tahun. Tanda dari hipertensi renovaskular adalah terjadinya peningkatan tekanan darah sistolik yang tidak dapat dikontrol dengan terapi hipertensi umumnya. Perlu dipikirkan pada anak-anak, remaja, wanita muda, dan pria yang menderita aterosklerosis kemungkinan adanya penyakit oklusi arteri renalis bila mereka menderita hipertensi. ${ }^{3}$

Retinopati hipertensi KW I sebagai tanda vaskular retina pada individu yang memiliki peningkatan tekanan darah. Pada keadaan hipertensi, pembuluh darah retina akan mengalami beberapa seri perubahan patofisiologis sebagai respon terhadap peningkatan tekanan darah. Terdapat teori bahwa terjadi spasme arterioles dan kerusakan endothelial pada tahap akut sementara pada tahap kronis terjadi hialinisasi pembuluh darah yang menyebabkan berkurangnya elastisitas pembuluh darah. Tahap awal, pembuluh darah retina akan mengalami vasokonstriksi secara generalisata. Hal ini merupakan akibat dari peningkatan tonus arteriolus dari mekanisme autoregulasi yang seharusnya berperan sebagai fungsi proteksi. pemeriksaan funduskopi akan terlihat penyempitan arterioles retina secara generalisata. Peningkatan tekanan darah secara persisten akan menyebabkan terjadinya penebalan intima pembuluh darah, hiperplasia dinding tunika media dan degenerasi hialin. Pada tahap ini akan terjadi penyempitan arteriolar yang lebih berat dan perubahan pada persilangan arteri-vena yang dikenal sebagai arteriovenous nicking. Tanda vaskular yang ditemukan bermacam-macam sesuai stadium. Pada retinopati hipertensi $\mathrm{KW}$ I ditemukan penambahan penciutan, ukuran pembuluh nadi dalam diameter yang berbeda - beda dan terdapat fenomena crossing pada pemeriksaan funduskopi. 5,6

Pendekatan konservatif dengan terapi medis bukan merupakan pilihan utama, setiap kasus harus dicari penyebabnya. Renografi captopril merupakan salah satu diagnostik yang sering dipakai untuk menilai fungsi dari keseluruhan perfusi dan fungsi, bukan untuk menilai vaskular tetapi pada pasien ini pemeriksaan diagnostik tersebut tidak dapat dilakukan karena keterbatasan fasilitas. Angiografi merupakan baku emas pemeriksaan pada stenosis arteri renalis karena dapat melihat stenosis pada proksimal arteri renalis, intrarenal atau arteri aksesoris. ${ }^{7}$

\section{DAFTAR PUSTAKA}

1. Labidi J, Touat D, Abdelghanim K, Ajili F, Ariba YB, Abdelhafidh NB, et al. Renovascular Hypertension: A report of 21 cases. Saudi J Kidney Dis Transpl. 2014; 25(1):96- 100.

2. de Moraes AC, Lacerda MB, Moreno LA, Horta BL, Carvalho HB. Prevalence of High Blood Pressure in 122, 053 adolescents: A systematic review and metaregression. Medicine (Baltimore). 2014; 93(27):232.

3. Wijaya P, Siregar I. Hypertensive crises in the adolescent: Evaluation of suspected renovascular hypertension. Acta med Indones. 2013; 45(1):49-54.

4. Drieghe B, Madaric J, Sarno G, Manoharan G, Bartunek J, Heyndrickx GR, et al. Assesment of renal artery stenosis: side by side comparison of angiography and duplex ultrasound with pressure gradient measurement. Eur Heart J. 2008; 29:517-524. 
5. Zhang HL, Sos TA, Winchester PA, Gao J, Prince MR. Renal artery stenosis: imaging options, pitfalls, and concerns. Prog Cardiovasc Dis. 2009; 52:209219.

6. Safian RD, Madder RD. Refining the approachto renal artery revascularization. JACC Cardiovasc Interv. 2009; 2:161-174.

7. Kim HJ, Do YS, Shin SW, Park KB, Cho SK, Choe $\mathrm{YH}$, et al. Percutaneous transluminal angioplasty of renal artery Fibromuscular dysplasia: Mid-term results. Korean J Radiol. 2008; 9(1):38-44. 